\title{
Animality, Sexuality and the Politics of Death in Mario Bellatin's Salón de belleza
}

Lucy Bollington, University of Cambridge

\begin{abstract}
In Bellatin's Salón de belleza aquariums filled with exotic fish function as the symbolic nexus through which queer bodies and destructive power intersect and become involved in mutational processes. This article brings the novella into dialogue with biopolitical philosophy, queer theory and posthumanism in order to conceptualise the multivalent implications of the text's trans-species reflections and crossings. My analysis moves beyond existing interpretations of the novella as a mournful account of the HIV/AIDS pandemic or as a text that documents violence more broadly, by calling attention to the more affirmative potentialities that are also latent in Bellatin's aesthetics of impersonality.
\end{abstract}

Salón de belleza by Mexican-Peruvian author Mario Bellatin was first published in 1994. In this novella, a nameless transvestite hairstylist tells of the transformation of his beloved beauty salon into 'un Moridero' (a dying place) after a nameless disease - el mal/ la peste - devastates a nameless city. When hospitals turn away the infected for fear of contagion, the narrator begins to take chronically ill men under his roof to prevent them from dying in the street. Over the course of the novella, the narrator, who also becomes infected with the disease, describes his life before and after the birth of the Moridero. He reminisces about 'cruising' for men on the city's streets and visiting underground bathhouses while the salon still existed. He also describes the complete control he now wields over the Moridero's voiceless dying bodies as he administers their mass death. The narrator gives pride of place in the narrative to his hobby of 'breeding' fish in the 'majestic' aquariums he constructed with the purpose of decorating his salon. The story of the lives and deaths of the fish that pass through these glass enclosures is interspersed with the story of faceless human death, so that the novella is effectively constructed through a series of reflections and crossings between species.

To a certain extent, Salón de belleza functions as a self-contained text and as such it differs from the author's later works, many of which are characterised by a 'cut-and-paste' textuality in which new novellas are created through mutated repetitions of symbols and narratives from Bellatin's existing works (see Epplin: 2015). While my focus here is on Salón de belleza itself rather than its mutational journeys, it is worth noting that the novella does have an afterlife within Bellatin's dispersive, metamorphic oeuvre: the fish, aquariums and disease are repeated, supplemented and transformed in works ranging from Biografia ilustrada de Mishima (2009) to Disecado (2011), and images of fish are also found in Bellatin's performative Instagram page, which represents an example of the author's extra-literary artistic tendencies. More broadly, nonhuman animals and posthuman imagery are recurrent in Bellatin's work, as exemplified by texts such as Perros héroes (2003) and La mirada del pájaro transparente (2005), and as such the exotic fish of Salón de belleza are prescient.

In what follows, I engage in an extended reading of the central human/animal relationship of Salón de belleza, examining how the fish function as a symbolic interface through which tropes of queer sexuality and destructive biopower intermix and become imbricated in transformational 
movements. Developing the theoretical framework of queer necropolitics to address the notion of 'species', I begin by examining the ways in which queer and animal subjectivities are affected by a common destructive power in Salón de belleza. My analysis will focus on the multiple forms of living death that mark human and animal existence in the novella, tracing the ways these interstitial states are brought about by the 'autoimmunitary' logic of broader society, the deadening inherent in the animal breeding market, and the necropolitical logic of the massacre that transforms bodies into disposable matter. Making recourse to the queer notion of 'disidentification', I then consider the extent to which the symbolic crossings between species carry more positive meanings. Introducing Roberto Esposito's notion of 'impersonality' at this juncture, I explore how Bellatin's trans-species crossings destabilise the necropolitical limitations and autoimmunitary imagery that his novella also foregrounds. In the final section, I examine how the impersonal disidentification that connects the men with the fish in the novella is also apparent in the text's evocative yet frustrated relation with its supposed context(s). Over the course of the article, I aim to show that rather than solely documenting tragedy, Bellatin's posthumanism also carries more affirmative ethical, political and aesthetic potentialities, which rest on the conceptual import of the novella's symbolic construction of a common ontological horizon.

Salón de belleza is the most widely read and discussed of Bellatin's literary texts, and as such I should like to begin by briefly reviewing the tendencies apparent in existing criticism on the novella. While the novella's central malady is never explicitly identified as HIV/AIDS, the text's queer subjectivities and publication date mean that this pandemic functions as a possible context, and this historical connection has given rise to readings of the novella as 'a melancholy coda to liberation' in Latin American queer cultural production, as Jean Franco puts it (2002: 274). Critics have argued that the novella traces a movement away from the 'utopia' or 'golden age' of the 'transgressive' body in health towards the 'dystopia of homosexual death' and the dehumanising loss of identity that occurs with the advent of the disease (Meruane 2014: 162; Lewis 2010: 128). To my mind, the implicit dichotomy constructed in these readings between a past liberation that is celebrated and the mourning task of the present forecloses the broader implications of Bellatin's text. Other readers have distanced themselves from the specific context of HIV/AIDS and interpreted the text as a conceptual reflection on such topics as the relation of violence to literary expression, notions of community, neoliberalism, the Mexican nation-state, and the state of exception (see Vaggione: 2009; Quintana: 2009; Roig: 2012). For instance, Silvia Roig contends that Bellatin uses the metaphor of disease to 'expose' the ways in which 'biopower operates in contemporary societies', and that he also calls attention to the deathly 'zone of indistinction between the human and the animal' (2012:42, 48). My analysis proceeds in the theoretical register of these works, but my engagement with posthumanism and Esposito's affirmative biopolitics open the way towards more positive readings of the text as well. Other readers have made nuanced observations about the ways in which Bellatin's novella employs the exotic fish to invoke - and frustrate - allegory, representation and literary or artistic traditions (such as Steinberg: 2011; Epplin: 2012; Larisch: 2015). I dialogue with these readings in the final section of this article in order to argue that the impersonal disidentifications thematised in Bellatin's text also extend to the text's at once resonant and refractive relationship with its own (imagined) context.

\section{Queer(ing) necropolitics}

Building on the insights about destructive biopower articulated by Michel Foucault in Society Must Be Defended, Achille Mbembe's theorisation of 'necropolitics' in 2003 represents a powerful example of 
political philosophy's attempt to conceptualise the ways in which power and politics are consolidated through the widespread inflection of death. Mbembe is concerned with 'the generalized instrumentalization of human existence and the material destruction of human bodies and populations' (2003: 14). He develops the concept of 'necropolitics' in order to confront the 'wounded and slain bodies' produced in today's spaces of conflict and social unrest, or 'death-worlds' as he terms them (2003: 30). In Mbembe's view, theories of biopolitics cannot adequately account for 'contemporary forms of subjugation of life to the power of death' (2003: 30). The bodies that exist in such spaces of conflict are disposable 'bodies in pain' who experience existence as a form of living death (2003: 29-30). Those that escape immediate death move within a fragmented territory that is increasingly experienced as a broken network of traumatic sites that 'bring back painful memories of humiliation... and beatings' (2003: 39). Moving beyond biopolitics, Mbembe argues that bodies are no longer inscribed within the 'disciplinary apparatus': 'When the time comes' they are inscribed within the 'maximal economy now represented by the "massacre" (2003: 34). Mbembe's theory of necropolitics is influential amongst artists and theorists in Mexico, most notably in the work of Bellatin's contemporary Cristina Rivera Garza. The recurrence of the politics of death in Bellatin's oeuvre implicitly contributes another layer to these broader cultural debates, although a comparison with other authors lies outside the scope of the present inquiry (see Epplin: 2015 for a brief but insightful comparison of Bellatin and Rivera Garza in relation to necropolitics).

In Bellatin's text necropolitical disposability is related to queer bodies. Even before the construction of the Moridero, the lives of the narrator and his friends are put in danger by the Banda de los Matacabros who violently police the city, restricting, through attacks and memories of attacks, the narrator's freedom of movement and ability to cross dress in certain areas (2011:12). As such, I am interested in considering how comparable ideas of living death take a central space in queer theory, as powerfully articulated in Butler's seminal text Bodies that Matter. The queer theory of bodily excess articulated by Butler in this work provides a generative point of encounter with Mbembe in light of the queer subjectivities in Bellatin's novella. At the heart of Butler's text is a comparable focus on 'unliveable' abject bodies that do not matter, and an attention to the 'inhabitable zones of social life' (1993: 3). Butler's central argument is that heterosexual bodies and identities are materialised through a hegemonic 'exclusionary matrix' (1993: 3). These heterosexual identifications rest on the 'simultaneous production of a domain of abject beings, those who are not yet "subjects", that is, on the abjection of queer alternatives to heterosexual materialisations of the body (1993: 3). In Butler's formulation, therefore, queer non-subjects function as an outside that exists inside the heteronormative subject as the constitutive repudiation that makes their sexed bodies legible. According to Butler, any identification with these queer bodies is repeatedly and persistently disavowed' by the regulatory norms that govern sexuality (1993: 3). In these ways, Butler, like Mbembe, is concerned with exclusionary spaces that produce forms of abject lifelessness, but Butler is focused on notions of psychological space rather than territoriality.

As a means of challenging this destructive form of power, Butler argues for destabilising the citational chain that governs sex and gender in order to produce opportunities for queer bodies to materialise as forms of valued life. She argues that such resistance to destructive power is 'crucial to creating the kind of community in which surviving with AIDS becomes more possible, in which queer lives become legible, valuable, worthy of support... without fixing the terms of that recognition in yet another conceptual order of lifelessness and rigid exclusion' (1993: 10). While some of the resistant strategies Butler discusses are at work in Bellatin's text - as we will see later in this article - it is not through 'life', 'value' and 'legibility' that Bellatin undermines rigid structures of exclusion, but through his posthuman transformation of the death space. 
Building on the insights of Mbembe and Butler, Jasbir Puar is commonly credited with first putting forward a theory of 'queer necropolitics' in her 2007 monograph Terrorist Assemblages. Puar's work is useful because it problematises the notion of life in a way that is generative for reading Bellatin's text. Puar's central argument is that in the contemporary era a certain queer identity is folded into life at the expense of entire populations that are queered and marked for death (2007:2). 'Life' is therefore produced at a heavy price. Focusing on the contemporary post-9/11 era in the United States, Puar traces the the powerful emergence of the disciplinary queer (liberal, homonormative, diasporic) subject into the bountiful market and the interstices of state benevolence...' (2007: xxvii), but notes how 'this benevolence towards sexual others' is fundamentally exclusionary and 'contingent upon ever-narrowing parameters of white racial privilege, consumption capabilities, gender and kinship normativity, and bodily integrity' (2007: xii). Puar argues that the emergence of the 'disciplinary queer' arises through the interweaving of narratives of 'sexual exceptionalism' and 'national exceptionalism', so that both notions become exclusionary signs that echo and enforce one another. She contends that through the emphasis on the 'transgressive' or liberatory' nature of queer sexuality that was prominent in the 1990s, queerness becomes 'the modality through which "freedom from norms" becomes a regulatory queer ideal that demarcates the ideal queer' (2007: 22). 'Homonormativity', a particular form of assuming life, is therefore complicit in the production of death-worlds elsewhere, and it operates through processes of fragmentation and exclusion.

Through my discussion of Bellatin's novella, I shall extend Puar's theory of queer necropolitics to include the idea of species so that multiple contestations of valued life and mechanisms of disposability are brought into focus alongside each other within a broader bio- and necropolitical economy. The blueprints for this extension beyond the human are foregrounded in the capacious terms used by Foucault to describe the biopolitics of racism, terms that were integral to the work of Mbembe and Puar and that have also been influential within animal studies (see, for example Wolfe: 2013). Foucault writes:

Racism makes it possible to establish a relationship between my life and the death of the other that is not a military or warlike relationship of confrontation, but a biological-type relationship: "the more inferior species die out, the more abnormal individuals are eliminated, the fewer degenerates there will be in the species as a whole, and the more I - as species rather than individual -can live, the stronger I will be, the more vigorous I will be. I will be able to proliferate" (2004: 255)

Bellatin's text resists the folding into life of one species at the expense of the death of another species, preferring instead to unite the aquatic and queer human 'populations' of his text in a common state of vulnerability and facelessness. As we will see, Bellatin's treatment of the fish and the humans ultimately undermines the notion of exceptional identity that is critiqued by Puar - indeed, the novella breaks down any notion of individual 'identity' at all - in favour of foregrounding a posthuman continuum and an impersonal experience of death. When Bellatin's text is read in dialogue with Puar, one realises that rather than solely mourning the demise of liberation' or documenting neoliberal or biopolitical violence, Bellatin's text opens up a new space of possibility through its destabilisation of the dynamic in which certain lives are sacrificed so that others can prevail.

\section{Necropolitical Unliveability}


Even before the salon becomes the Moridero in Bellatin's novella the living death that characterises necropower is present in the narrator's hobby of breeding fish, a hobby that occupies a prominent textual space throughout the novella, functioning as a thematic refrain. The living death exhibited by the fish is initially evident in the artificiality of their built environments, which the narrator describes in great detail. The aquariums and the fish are purchased with the purpose of decorating the salon in order to make it stand out from other businesses. The aquariums include ornaments such as air pumps disguised as 'frog men' or 'treasure chests lying on the bottom of the sea' (Bellatin 2011: 12); they are enclosures designed with the purpose of masking and adorning life. In such decorative settings, the fish become objects of human contemplation and pleasure in much the same way as a painting. Craig Epplin has argued that Bellatin's novella is more akin to a museum than a traditional literary text, comparing it in particular with the experimental museums set up in personal homes by artists in the 1990s in Mexico (2012: 106, 111). Here I want to tie these ideas of display and exhibition to the history of the artificial containment of animals, with reference to the zoo rather than the museum. John Berger famously commented that spectacular caged environments, such as zoos, where 'all animals appear like fish seen through the plate glass of an aquarium', function as a 'monument' to the 'disappearance' or 'marginalisation' of animals with the ascendency of human culture (1980: 14-24). In this tradition of thought, "human advance coincides with the retreat of the animal, though animals do not disappear completely and live in a state of perpetual fading, hence their figure has become spectral, like that of the living dead', as Valeria de los Ríos puts it (2005: 38). In this view, the expanding life of one species (the human) is premised on the simultaneous marking for living death of other species. Varying Puar's terms, this process can be described as a form of 'posthuman necropolitics'. However, as I shall demonstrate shortly, Bellatin departs from this lifedeath conflict between species by having both the human and the fish occupy a common death-space.

It is not simply the artificiality of their built environments that leads to the deadening of animal life in Bellatin's text. There is also something in the logic of the breeding market that implies disposal. When the narrator first enters the fish store to begin his breeding hobby, he is told that Royal Guppies are 'the ideal fish for a beginner' (Bellatin, 2011: 11). Different fish require different levels of care to maintain, the fish store explains, so the breeder should begin with an easy or more common fish before progressing to more difficult and unusual types. While the message is ostensibly delivered with a view to making the person better at caring for life, this message also arranges animal life across a spectrum of value and achievement. The narrator's actions towards the fish work to draw out the violent message concealed within this market logic of progression. The narrator reflects 'I get tired of things that attract me extremely quickly...First it was the guppies which at some point seemed to me to be too insignificant for the majestic aquariums I was envisioning...I gradually stopped feeding them. I hoped that they would eat each other. I threw the survivors into the toilet...' (Bellatin, 2011:13).

Through the narrator's violent actions, the reproduction of the lives of certain majestic and valued types of fish occur at the expense of the early disposal of others that are deemed to be more expendable. The necropolitical drift of this biopolitical breeding project reveals the frequently concealed bio-necro connection, the reality that '[biopolitics] masks the multiplicity of its relationships to death and killing in order to enable the proliferation of [necropolitics]' as Puar puts it (2007: 35). While the narrator repeatedly ties the fish to the idea of life in the text, their obvious deadening works to frame life in a particular way. Specifically, the deadening and disposal of the fish suggests that Bellatin does not relegate necropower to an aberrant space, but points to its proliferation within life processes.

The trace of death that lurks within the breeding market and within aestheticised forms of life has implications for the interpretation of the relationship between human life and death in the text. 
Some critics have read the movement from the salon to the Moridero in binary terms, contending that the text maps a departure from the 'halcyon days' of the beauty salon towards the tragedy of human death (Lewis 2010: 128). Yet as Sergio Delgado notes perceptively in his reading of the corporeal aesthetics of the text, the salon is in fact already tainted by the mark of death, for the salon's beauty treatments, which are on the whole directed towards ageing women, work according to the logic of masking death, of concealing its steady onset through the reproduction of images of life (2011: 77). A certain form of life can be (re)produced through consumer materials that adorn, supplement and enclose the body, much in the same way as the fish tanks produce a sort of life that masks, and yet reveals, a constant deadening.

The full face of necropolitics emerges with the advent of the nameless disease in the novella. Initially, this is evident through the destructive power exercised by broader society towards the queer community. Public hospitals abandon their caretaking function and reject patients 'for fear that the men are contagious', treating those suspected of contracting the disease with 'disdain' (Bellatin, 2011: 12). As well as the public hospitals, the diseased population of Bellatin's novella also have to contend with the destructive actions of the general populace. For example, the neighbours of the Moridero mount campaigns to have this building destroyed due to their fear that the disease had 'spread into their homes' (Bellatin, 2011:21). Only the rancid smell of decomposing flesh and the 'fear of contagion' seem to hold them at the front door (Bellatin, 2011:22). As these examples convey, the hospitals and neighbours abandon or act against the diseased community out of their desire to protect individual and broader public health. Accordingly, their destructive actions can be understood with recourse to the 'immunitary' and 'autoimmunitary' paradigms that Roberto Esposito puts forward when developing his theory of 'thanatopolitics' in relation to Nazi Germany. As with necropolitics, Esposito's thanatopolitics seeks to conceptualise the destructive elements of modern biopower. 'Autoimmunity' describes a political condition in which society attacks part of itself, 'the ultimate condition in which the [immunitary] protective apparatus', which Esposito associates with biopolitical modernity, 'becomes so aggressive that it turns against its own body (which is what it should protect), leading to its death', and this aggression is linked to an unchecked security logic rooted in the ideal of the healthy body politic (2008: 116). The socio-political logic of autoimmunity thereby echoes the autoimmune image of the disease that circulates in the novella. Necropower works in tandem with the biomedical pandemic to transform bodies into disposable matter.

This autoimmunitary social logic is connected to broader social conceptions of illness that persistently position the ill body beyond the nation. As Susan Sontag and Paula Treichler both note in their now classic critiques of the discursive basis of AIDS, the ill bodies affected by this pandemic when it 'emerged' in the early 1980s were transformed into symbols of degeneration, grouped together as 'risk' populations, and depicted as the social enemy. Sontag notes how 'the excommunicating and stigmatization of the ill' occurred through the military metaphors of AIDS, proclaiming 'we are not being invaded. The body is not a battlefield. The ill are neither unavoidable casualties nor the enemy. We - medicine, society - are not authorised to fight back by any means whatsoever...' (1989: 94). Treichler traces the ways these military metaphors increasingly gave way to postmodern metaphors of codes, transmissions and terrorism in the 1980s, a change that reflected developments in technology and the shifting nature of the social 'enemy' (1987: 282). Rather than being figures of care, ill bodies are forcibly relegated to a zone of abandonment, and Bellatin's novella resonates with this context, while nevertheless refusing to name or fully represent it (as will be discussed in the final section).

In the case of Salon de belleza, the illness and the social abandonment it provokes provide another point of connection between the human and the animal. As with the historical AIDS pandemic, the nameless disease in the novella is zoonotic (it moves between species). The same 
'fungus' is found on the skin of the men and the skin of the fish, and the fish begin to die at the same time as the men. When a favoured 'guest' of the narrator's dies, for example, the narrator reveals that 'three fish died with the boy' (Bellatin, 2011: 18). As Nicole Shukin notes in her book Animal Capital, zoonotic pandemics are commonly 'productive of a ruthless species hierarchy that rationalises the segregation and sacrifice of (nonhuman) bodies suspected to be infected so that others (human) may live...' (2009: 186). Pandemics intensify the posthuman necropolitics mentioned previously, through which human advance takes place at the expense of the fading of animal life. However, Bellatin upsets this hierarchy of the 'biomobile' pandemic in his novella (to use Shukin's terms for zoonosis). On the one hand, Bellatin's narrator seems more concerned that his precious fish have contracted the human disease rather than the other way around. On the other hand, the novella ultimately transforms 'contagion' into a destabilising symbol that denotes the broader life-death continuum that connects species together rather than separating them through acts of violence.

With the birth of the Moridero, the human population, like the fish, come under the control of a necropolitical sovereign figure: the novella's narrator. Within the space of the Moridero, the instrumentalised quality of mass death that Mbembe describes is evident in the narrator's 'management' of the death of the humans and the fish. As Mary Louise Pratt notes, the narrator demonstrates 'a hyper-rationalistic, instrumental and depersonalised character' (2002: 99), to the effect that 'the epidemic in Salón de belleza is not only AIDS, it is also a rationalistic mentality' (2002: 100). While they are 'guests' in the Moridero, the dying men are approached through a welldefined administrative routine: they are given one bowl of the same soup each day, which gets smaller in size in order to expedite the passage from life to death. In the novella, the dying men have no voice, face or individuality, and the narrator strives to take any remaining hope away from the men so that 'the possibility they might ask about their condition no longer exists' (Bellatin, 2011:23). By comparison, the narrator stops cleaning the water of the fish tanks and stops feeding them so that the fish are similarly slowly deprived of necessary sustenance. Due to these acts on the part of the narrator, the fish and the humans come to occupy the same state of 'total lethargy' (Bellatin, 2011: 23), a vacated and absent form of subjectivity that takes the form of death even though the subject has not quite arrived at its final (biological) moment of demise.

Under the complete control of the narrator, both the humans and the fish exist in an interstitial place where life and death become necropolitical decisions more than biological or scientific facts, in a manner reminiscent of Giorgio Agamben's exploration of the 'thanatopolitical' face of biopolitics (1998). The continued existence of both species is ultimately subject to the whims of the sovereign figure of the private breeder turned manager-of-mass-death, who can sustain or withdraw life according to his whims, needs or desires. The economy of the 'massacre' that Mbembe discusses is evoked in Bellatin's text through the narrator's final disposal of animal and human bodies. After the men die, they are dumped unceremoniously into 'a mass grave' and any family members that ask after these bodies are simply told that 'they are no longer in this world' (Bellatin, 2011: 24). As in the example provided earlier, the fish are flushed down the toilet or left to asphyxiate.

In light of these images of mass death, critics have likened Bellatin's Moridero to a concentration camp, a term that occupies a foundational place in the theoretical genealogy of necropolitics. For instance, drawing on the work of Agamben, Lina Meruane describes the aquariums as a 'miniature concentration camp' and argues that the Moridero as a whole 'echoes the logic of Nazi genocide' (2014: 167-168). Similarly, Alicia Vaggione describes the Moridero as 'a zone of exception', pointing to the loss of rights of the bodies that populate this space due to the narrator's strict rules (the narrator does not allow doctors, medicine or religion in the Moridero, for example) (2009: 497). Of particular relevance here is the strong presence of the animal in discussions of the 'camp' in 
political philosophy. For instance, Esposito argues that 'Nazi politics wasn't even a proper biopolitics, but more literally a zoopolitics, one expressly directed to human animals' (2008: 117). Giorgio Agamben, on the other hand, discusses how the camp creates an indistinguishable zone of man and beast, a space of 'bare life' or $z o \bar{e}(1998)$. In these political theories, the animal seemingly becomes a fluid political frame that is applied flexibly to refer to populations that are stripped of their rights violently. As animal theorist Cary Wolfe puts it, "the distinction "human/animal" - as the history of slavery, colonialism, and imperialism well shows - is a discursive resource, not a zoological designation; it is... a kind of dispositif or apparatus' (2013: 10), and therefore we are all 'potentially animals before the law' (2013: 105) depending on the particular political circumstance we find ourselves in. Bellatin's inclusion of fish in the death-space, animals that denote extreme disposability in contemporary culture, appears to be working in this vein. The fish, on one level, function as symbols used to denote the reduction of bodies to disposable matter in a conceptual autoimmunitary context.

\section{Posthuman Disidentification}

I have been developing an argument that the men and the fish mirror each other in Bellatin's Moridero. With recourse to queer theory, I would now like to draw out the aspects of this human/non-human mirroring that implicitly challenge the novella's necropolitical and autoimmunitary drift.

The mirror takes a prominent space in psychoanalytical materialisations of the gendered, heteronormative body, as Butler points out (1993). But the site of reflection can also be used to destabilise these formulations. Butler proposes that we resist the destructive power inherent in the exclusionary process of (heterosexual) identification through disidentification. Disindentification, in the sense Butler deploys the term, is the process that reveals the principles of corporeal transferability at play within existing psychoanalytical projections of the body. Working through the constraints and prohibitions of dominant power structures, disidentification paves the way for a destabilisation of the heterosexual imperative that fixes body parts in certain (heteronormative) hierarchies. The gesture of un-forming rather than reformulating identity that disidentification instigates works against the exclusionary nature of identity in general (the reality that all coherent subject positions inevitably rest on the production of an abject, lifeless outside) (1993: 114), and, for this reason, Butler observes that 'although the political discourses that mobilize identity categories tend to cultivate identifications in the service of a political goal, it may be that the persistence of disidentification is equally crucial to the rearticulations of democratic contestation' (1993: 4).

Bringing together this queer strategy of resistance with the animal imagery in Bellatin's text, I would like to suggest that Bellatin's text implicitly foregrounds a posthuman version of queer disidentification. There is a posthuman corporeal transferability at play through the excessive textual movements, reflections and (partial) cross-species becomings. The glass panes of the aquariums are constantly crossed, and through these crossings the exclusionary boundaries of individual subjectivities and individual species begin to merge and dissolve. For example, the narrator uses the empty aquariums to store the materials associated with the Moridero's human guests, even sticking labels on the fish tanks that correspond to the names of the guests so as to avoid confusion (Bellatin, 2011: 12). Delgado evocatively notes that through this process of storage, the fish tanks become 'coffins' for the living attributes of the human guests (2011: 78). The space of animal deadening thus becomes a space related to human deadening as well. The narrator also inserts his own body inside the aquariums, revealing that 'sometimes, when nobody can see me, I place my head in the fish tank and even touch the water with the point of my nose' (Bellatin, 2011: 18-19). The narrator even 
dresses in the same colour as the fish at certain points in the novella, enacting another form of 'cross dressing' that takes him not only beyond a certain social construction of gender but also beyond the performance of species. He reveals: 'when I became interested in golden carps... I would always adorn the dresses I wore at night with something gold' (Bellatin 2011: 12). Moreover, the narrator fantasises about flooding the Moridero shortly before his own death in order to transform it into 'a giant aquarium' (Bellatin 2011: 34), therefore breaking down any remaining 'physical' barrier between the species. While the human inserts itself into the space and the form of the fish, therefore, the fish threaten to cross the glass panels of their aquariums and unite with the humans in the broader space of the Moridero-turned-fish tank.

While the necropolitical body is defined by its confrontation with destructive, painful 'limitations' in Mbembe's theory and in Butler's work on queer abjection, Bellatin's human/animal crossings work to break down these exclusionary matrices in favour of the production of a posthuman continuum. This continuum is created through processes of crossing, and enhanced by the common condition of facelessness and voicelessness that unites the dying humans and the fish in Salón de belleza. Posthuman necropolitics is no longer seen as divisive in the tradition of Puar's queer necropolitics: it comes to denote a form of interconnectivity that emerges through the common site of death.

Read in this vein, Bellatin's intersection of queer humans and animals is far removed from the historical uses of animal imagery to stigmatise queer sexualities as 'uncivilised'. In his book Formas comunes, Gabriel Giorgi observes a similar change in the discursive and aesthetic relationships between queer identity and animality in the work of Argentine writer Manuel Puig. Giorgi argues that in Puig's novel El beso de la mujer araña the animal no longer marks an exclusionary or stigmatised space, but rather the conjoining of queer and animal imagery in the text speaks to a 'threshold' of different possibilities for 'becoming a body', a threshold in which 'affects and alternative meanings emerge' and circulate (2014: loc 2987).

The potentialities that Bellatin's novella opens up, however provisionally, can be drawn out with recourse to Esposito's philosophy of 'impersonality'. Impersonality, which unites human and nonhuman forms of life along an immanent plane, is Esposito's attempt to think a form of collective life marked by a shared vital experience. Through the development of a new philosophical lexicon, impersonality seeks to overturn the thanatopolitics that emerges when modern immunity - the aporia of modern community, its 'intimate essence' (Campbell 2008: xii) - degenerates into autoimmunitary, self-destructive excess. Drawing on the thought of Gilbert Simondon and Gilles Deleuze, amongst others, Esposito invokes 'impersonality' in order to theorise an affirmative biopolitics that rests on 'a conception of life that is aporetically exposed to others in such a way that the individual escapes an immunisation of the self (and hence is no longer an individual proper)' (Campbell 2008: xxix). Quoting Deleuze, Esposito writes that from an impersonal perspective 'the living lives at the limit of itself, on its limit', which he describes as 'a crease in which subject and object, internal and external, and organic and inorganic are folded' (193-194) - a shared space of individuation that the 'individual' always exists in relation with. In dialogue with Esposito, I would suggest that Bellatin's impersonality poses a conceptual counterforce to the novella's autoimmunitary symbolism, even if this impersonality is provisionally articulated in a space of dying, at the outer limit of life, an outer limit that is nevertheless involved in transformational processes.

Esposito's work on impersonality contains a nuanced sense of the interrelation of life and death (as is clearly apparent in his readings of Simondon and Deleuze), yet semantically at least Esposito emphasises 'life' (albeit in an utterly reworked sense). Explicitly addressing the semantics of death, which have clear relevance to Bellatin's text, Rosi Braidotti puts forward a theory of 'posthuman necropolitics' which similarly seeks to deplete ontological barriers while emphasising the 
importance of death's impersonal integration into a posthuman death-life continuum. Braidotti writes that death marks the becoming-imperceptible of the subject as the furthest frontier of the processes of intensive transformation or becoming' (2013: 135), continuing that 'writing as if already gone, or thinking beyond the bounded self, is the ultimate gesture of defamiliarisation. This process actualises virtual possibilities in the present, in a time sequence that is somewhere between the "no longer" and the "not yet", mixing past, present and future into the critical mass of an event' (2013: 137). These comments resonate with Bellatin's novella, which, starting in medias res, does not 'begin' as such, nor does it ever reach an end, and remains in the temporality of dying and death, which, for Braidotti, is the temporality of impersonal and ethically sustainable 'life' itself. When read in dialogue with Esposito and Braidotti, it thus becomes possible to trace the latent contours of an affirmative opening in Bellatin's posthuman rendering of the death space, located in the novella's shift towards an immanent vision of existence.

\section{Impersonal Aesthetics}

The image of crossing into the aquarium also has broader resonance within Latin American literary history. In particular, Bellatin's crossings are reminiscent of Julio Cortázar's influential short story 'Axolotl', which has had an important discursive legacy within Latin American Studies. In Cortázar's story, the narrator is transfixed by the axolotls that he visits at a zoo. As the story develops, the narrator undergoes a metamorphosis, gaining the form of the axolotl and falling from the exterior side of the fish tank to the interior. The story contains a series of meditations on the fluid reality of notions of humanness and otherness. However, the narrator ultimately feels he can never quite access the axolotl, even after he takes on their corporeal form. Due to the pre-colonial history of the axolotl, Cortázar's story has been read in relation to discourses of Latin American identity. Brett Levinson has argued persuasively that Cortázar's story plays 'subversively' with the trace of ancestral heritage, both linguistically and thematically (1994). According to Levinson, Cortázar foregrounds cultural 'alienation' rather than connection, upsetting identitarian thinking about Latin America and Latin Americans (1994: 11-17).

Axolotls - or ajolotes as Bellatin calls them, using the Spanish term that Cortázar moves away from - do make a brief appearance in Bellatin's text. The ajolotes are only a few of the many types of aquatic life that pass through the Moridero's aquariums, and they function less as objects of fascination for Bellatin's narrator than as objects of disgust. The ajolotes are depicted as predatory, violent and 'secretive' beings, and the narrator states that the 'appearance' of the ajolotes contributed to their 'unpleasant style', imbuing the act of breeding them with 'a diabolical character' (2011: 2930). I do not mean to imply that Bellatin is making a connection between these qualities and Mexican or Latin American identity. Rather, the ajolotes appear completely divorced from references to history and place, and they no longer function as some sort of biological metaphor or mirror that undergirds nationhood and national identity. In Bellatin's novella, ajolotes are merely judged on the basis of their present appearance and behaviour, and they do not appear to carry any broader (national/ regional) value. Moreover, the narrator's relationship with the fish that he admires in the text (such as the golden carp) is explained with reference to unspecified foreign cultures. The narrator speaks vaguely of his contemplative relationship with the fish as comparable with foreign 'pastimes', pleasures and traditions (Bellatin, 2011: 12). The game of reflections that Bellatin sets up between the humans and the fish is therefore disjointed from national space, and in this way Bellatin goes further than Cortázar's subversive unhinging of ancestral ties. Bellatin's treatment of the axolotl/ajolote, and introduction of other types of fish, seems to be reflective of Roger Bartra's observation that: 
Mexicans recognise themselves less and less in [the] axolotl, which offers them a reflection of national culture as a paradigm of unifying national stoicism. There are lots of Mexicans that do not wish to return to the axolotl...they have lost their identity, but they do not lament this...they are others, they are different (1996: 199)

The idea of textual disidentification thus extends to the symbolic arena of national identity formation. Any appeal to exceptionality - whether on the basis of nationalism, humanism or queer identity looses itself in the broader posthuman continuum of Salón de belleza.

The disidentification implicit in the unmoored employment of the axolotl provides an occasion for a broader reflection on the text's relation to its imagined context. Critics have made important arguments about how Salón de belleza relates to, and frustrates, allegories pertaining to the nation. For instance, Steinberg has argued that the fish of Salón de belleza ultimately distract the narrator from completing an allegory about the historical AIDS pandemic or neoliberal violence in general, and contends that if Bellatin's writing allegorises anything it is the 'withdrawal of the literary' from its 'annexation' to politics, the very 'groundlessness of writing and the arts in the face of the consensual neoliberal project that threatens to become the horizon of the world as such' (2011: 112-115). Similarly, Sharon Larisch observes that the fish become part of the hyper-allegorical movements underway in the novella, which displace the reader from their usual 'interpretative' role (because the text seems to contain its own interpretations) (2015: 512-513). Moreover, through her focus on the production of space in Bellatin's text, Larisch advances the perspective that 'although allegory understood in a particular spatialised way, as representation through a one-to-one correspondence, fails, the space time of allegory as ruin or...residue evades the textual closure', and she contends that this renewed sense of allegory offers an opening towards politics (2015: 518).

To my mind, the novella is marked by a duality when it comes to the question of context. It contains symbols that resonate with the HIV/AIDS pandemic and with necropolitical and autoimmunitary patterns of violence more broadly, as I have evoked. Working on a conceptual level, the common ontology the novella constructs also creates an opening towards a relationality that implicitly overturns a politics of death rooted in the killing of some so that others might live. Yet as the disjunction of the axolotl and the interventions made by Steinberg and Larisch make clear, the novella never fully fleshes out or represents any specific extrinsic context or historical occurrence. The tropes of disidentification and impersonality that I have introduced can be extended to conceptualise this dualistic connection to context. Just as disidentification mutates the terms of 'reflection', transforming reflection into something more akin to refraction as it facilitates the partial posthuman transformation of one species towards another, so too a form of textual disidentification unhinges the text from the national/historical, exceeding the bounds of representation, or functioning at its outermost limits. Similarly, the movement beyond the social and towards a reciprocity of relations between entities that characterises Esposito's impersonality - which is also beyond 'representation' in the political sense of this term (Campbell 2010: 141) - can be expanded to think of Salón de belleza's movement beyond a specific (social/ national) outside and towards the literary relationality that characterises Bellatin's oeuvre. As I indicated in the introduction, the novella's symbols and themes are repeated and mutated in future works and thus recuperated into Bellatin's textual network. In other words, the impersonal, affirmative politics latent in the text's posthuman imagery also function through Bellatin's dispersive aesthetics, rooted as they are in posthuman symbolic interconnections that bear a refractive relation to the social while frustrating representation.

\section{Conclusions}


In a brief number of pages, Salón de belleza symbolically contests its own necropolitical figurations. Bellatin's novella evokes the autoimmunitary drive of biopolitical modernity, the destructive power dynamics of disposal and mass death, and the common abandonment experienced by humans and animals alike within a necropolitical landscape. However, Bellatin's invocation of the politics of death also carries with it more positive meanings. Through the idea of disposal, which is at the heart of the necropolitical experience, the singular body spills out from itself and joins a broader impersonal matrix. 'Inhabitability', the inability to dwell in one's own space, becomes the site of possibility for posthuman interconnections, crossings and partial becomings that take place in a time of dying. The fish are metaphors of disposability in the novella, but they are also central to an impersonal reworking of the politics of death that is thematised in the text and embedded in Bellatin's wider literary aesthetics. In an environment where every folding into life represents another marking for death, the notions of disidentification and impersonality foregrounded in Salón de belleza provide openings that carry political, ethical and aesthetic potentialities. Moving beyond readings that suggest the novella primarily works to document tragedy or to conceptualise violence, I have aimed to demonstrate that Bellatin's text is also engaged in a conceptual mutation away from destructive power, however latent and provisional this shift remains.

\section{Notes}

1. Unless otherwise indicated in the references below all translations from Spanish are my own.

\section{References}

Agamben, G. (1998) Homo Sacer: Sovereign Power and Bare Life. Trans. by Daniel Heller-Roazen. Stanford University Press: Stanford, CA.

Bartra, R. (1996) La jaula de la melancolía: identidad y metamorfosis del mexicano. Grijalbo: México, DF.

Bellatin, M. (2011) Salón de belleza de belleza. In Obra reunida. Alfaguara: Madrid.

Bellatin, M. (2011) Biografía ilustrada de Mishima. In Obra reunida. Alfaguara: Madrid

Bellatin, M. (2001) Disecado. Sexto Pisto: México, D.F.

Bellatin, M. (2011) Perros héroes. In Obra reunida. Alfaguara: Madrid.

Berger, J. (1980) About Looking. Pantheon Books: New York.

Braidotti, R. (2013) The Posthuman. Polity: Cambridge. 
Butler, J. (1993) Bodies that Matter: On the Discursive Limits of 'Sex'.

Routledge: London.

Campbell, T (2010) “Foucault was not a person”: Idolatry and the Impersonal in Roberto Esposito's Third Person'. CR: The New Centennial Review 10(2): 135-150.

Cortázar, J. (1970) Relatos. Editorial Sudamérica: Buenos Aires.

Delgado, S. (2011) 'Estética, política y sensación de la muerte en “Salón de belleza” de Mario Bellatin'. Revista Hispánica Moderna 64 (1): 69-79.

De los Ríos, V. (2015) 'Look(ing) at the Animals: The Presence of the Animal in Contemporary Southern Cone Cinema and in Carlos Busqued's Bajo este sol tremendo'. Journal of Latin American Cultural Studies 24(1): 33-46.

Epplin, C. (2012) 'Mario Bellatin y los límites del libro'. In Julio Ortega and Lourdes Dávila (eds), La variable Bellatin: Navegador de lectora de una obra excéntrica. Universidad Veracruzana: Xalapa, Veracruz.

Epplin, C. (2015) 'Mario Bellatin: Literature and the Data Imaginary'. Revista de Estudios Hispánicos 49 (1): 65-89.

Esposito, R. (2008) Bíos: Biopolitics and Philosophy. Trans. Timothy Campbell. University of Minnesota Press: Minneapolis, MN.

Franco, J. (2002) The Decline and Fall of the Lettered City: Latin America in the Cold War. Harvard University Press: London.

Foucault, M. (2003) "Society Must be Defended": Lectures at the Collège de France, 1975-76. Eds. Mauro Bertani and Alessandro Fontana. Trans. David Macey. Allen Lane: London.

Giorgi, G. (2014) Formas comunes: animalidad, cultura, biopolítica. Available at: https://www.amazon.co.uk/kindle-ebooks (Downloaded: 5 May 2016).

Larisch, S (2015) 'Mario Bellatin's Salón de belleza and the Production of Space'. Revista de Estudios Hispánicos 49 (3): 503-524.

Levinson, B. (1994) 'The Other Origin: Cortázar and Identity Politics'. Latin American Literary Review 22 (44): 5-19.

Lewis, V. (2010) Crossing Sex and Gender in Latin America.

Palgrave Macmillan: New York.

Mbembe, A. (2003) 'Necropolitics'. Trans. Libby Meintjes. Public

Culture 15(1): 11-40. 
Meruane, L. (2014) Viral Voyages: Tracing AIDS in Latin America. Trans. Andrea Rosenberg. Palgrave Macmillan: New York.

Pratt, M. L. (2002) 'Tres incendios y dos mujeres extraviadas: el imaginario novelístico frente al nuevo contrato social'. In Mabel Moraña (ed.), Espacio urbano, comunicación y violencia en América Latina.

Instituto Internacional de Literatura Iberoamericana: Pittsburgh, 91-106.

Puar, J. (2007) Terrorist Assemblages: Homonationalism in Queer Times.

Durham University Press: London.

Quintana, I. (2009) 'Escenografía del horror: cuerpo, violencia y política en la obra de Mario Bellatin'. Revista Iberoamericana LXXV (227): 487-504.

Roig, S. (2012) ‘QQué significa vivir en un Estado de derecho?: vida, contaminación y muerte en Salón de belleza de Mario Bellatin'. Lucero 22: 39-54.

Shukin, N. (2009) Animal Capital: rendering life in biopolitical times.

University of Minnesota Press: Minneapolis.

Sontag, S. (1989) AIDS and its Metaphors. Farrar, Straus \&

Giroux: New York.

Steinberg, S. (2011) 'To Begin Writing: Bellatin, Reunited'. Journal of Latin American Cultural Studies 20(2): 105-120.

Treichler, P. A. (1987) 'AIDS, homophobia and biomedical discourse:

An epidemic of signification', Cultural Studies 1:2, 263-305

Vaggione, A. (2009) 'Literatura/ Enfermedad: El cuerpo como desecho. Una lectura de Salón de belleza de belleza de Mario Bellatin'. Revista Iberoamericana. LXXV: 227: 475-486.

Wolfe, C. (2013) Before the Law: Humans and Other Animals in a Biopolitical Frame. The University of Chicago Press: Chicago. 